\title{
TRAGEDY OF WOMANHOOD WITHIN PATRIARCHY: AN ANALYSIS OF GENDER AND SEXUALITIES IN IBSEN'S A DOLL'S HOUSE
}

\author{
S. G. Hewa ${ }^{1}$
}

Department of English, University of Kelaniya, Kelaniya, Sri Lanka ${ }^{1}$

\begin{abstract}
A Doll's House (1879) by Henrik Ibsen (1828 - 1906) is a play that follows the trajectory of Nora, a woman belonging to the $19^{\text {th }}$ century Norwegian society, who has been forced to stifle her vibrant personality to survive within a male dominated system. Ibsen successfully presents an authentic glimpse of life through the experiences of a woman who is beginning to realize the suppression she has been subjected to as a result of the rigid understandings of gender and sexualities perpetuated through patriarchal ideologies. This play becomes an ideal platform to examine how women are governed by socially prescribed identities that destroy their agency and freedom. The main research problem addressed in this study is whether gender and sexualities are discursive constructions that oppress and marginalise women within the patriarchal social structure. The idea of performativity introduced by Judith Butler is used as the central framework through which this idea is explored. Moreover, feminist theories presented by Simone de Beauvoir, Helene Cixous, bell hooks, Gilbert and Gubar will also be referred to within the research to support the arguments formulated. A textual analysis of the play was conducted to explore the fluidity and artificiality of the concepts of gender and sexuality. Accordingly, the central findings of the research highlighted the fact that gender and sexuality are discursive constructions that relegate women into marginal positions. This qualitative study will contribute towards the understanding of gender and sexuality as social and cultural productions that sustain hegemonic ideologies and power hierarchies.
\end{abstract}

KEYWORDS: A Doll's House, Ibsen, Gender, Sexuality, Performativity, Patriarchy

Corresponding Author: S.G. Hewa, Email: sashaghewa1997@gmail.com 


\section{INTRODUCTION}

A Doll's House (1879) by Henrik Ibsen (1828 - 1906) is a well-made play that explores complex facets of gender and sexual identities. As a playwright, Ibsen is heavily influenced by Naturalism that stresses the need to capture the reality of daily life, human behaviour, actions, and relationships. His plays reveal an attempt to present the audience with a "slice of life" (crossrefit.info, 2021, p. 1) through which they can understand and analyse their own lives. In this drive to explore human nature through his work, Ibsen addresses many issues faced by women in his contemporary society. Set in $19^{\text {th }}$ century Norwegian society, this play provides a glimpse of the discriminatory practices of patriarchy that marginalise and oppress women. Nora in A Doll's House (1879) is a woman trapped within her socially imposed role and is forced to endure an oppressive marital life while suppressing her desires. She is a vivacious woman who is forced to smother her sexuality, creativity and energetic nature to survive within a patriarchal society. Nora's trajectory is reflective of social norms and expectations that function upon the basis of gender and sexuality. She lives in a society where women are marginal characters within the larger political, social and economic spheres that operate under patriarchal ideologies. Women who dared to stray from these rigid boundaries were chastised and ostracized from society.

Walby (1990) defines patriarchy “as a system of social structures and practices in which men dominate, oppress and exploit women" (Walby, 1990. p. 20). This oppression is rooted in the representation of women as inferior to that of their male counterparts. These conventional understandings of womanhood and femininity can be further discussed through the concepts of sex and gender. Traditionally, as mentioned in the text Gender Trouble (1990) by Judith Butler, 'sex' was regarded as an essential, biological and natural aspect that is pre-determined and fixed, whereas gender is the acquired cultural and social values by which men and women function. Hence, gender identities are assigned according to the anatomical differences between men and women. Butler (2006) is critical of this dichotomous distinction between the sexes as it becomes the primary source through which gender roles and sexual desire are regulated.
Accordingly, she argues that "gender is the cultural interpretation of sex" (Butler, 2006, p. 10). This argument is further developed by showing how "sex is as culturally constructed as gender" (Butler, 2006, p. 9). This understanding is used as the central framework within which the play A Doll's House (1879) has been analysed in this research. Although, this play has been previously analysed within a feminist framework, the existing research does not adequately address whether gender and sexualities are discursive constructions. Furthermore, how patriarchal ideologies perpetuate rigid definitions of gender and sexualities that acclimatize women into peripheral positions has not been discussed in depth. This is the research gap the current study attempts to fill.

\section{METHODOLOGY}

A textual analysis of the drama A Doll's House (1879) by Henrik Ibsen was conducted based on a subjective ontological perspective. The main research problem addressed in this research is whether the concepts of gender and sexual identities are discursive constructions that marginalise and oppress women within the patriarchal social system. This idea is examined in light of how Nora, the female protagonist of $A$ Doll's House (1879) becomes a victim of rigid societal conditions that aim to restrict and discriminate women. This research is a non-positivist and qualitative study that is based on the ontological assumption that the concepts of gender and sexuality are constructed through hegemonic discourses and power hierarchies. Moreover, it is assumed that these gender and sexual identities are fluid and multifaceted. A constructivist epistemological stance has been adopted to understand how the concepts of gender and sexuality are subjectively experienced and constructed. A feminist theoretical framework has been used to analyse the various nuances of gender and sexuality that can be highlighted in the play $A$ Doll's House (1879). The theories of Judith Butler, Simone de Beauvoir, Helene Cixous, bell hooks, Gilbert and Gubar are some of the central concepts referred to within the research. The ideas of performativity, construction of gender, reclaiming agency over mind and body, marginality as a site of resistance, dichotomized readings of womanhood presented by these theorists will be given focus in this study. The setting, historical context, 
dialogues, actions, stage directions, character portrayals and the plot-line of this drama were analysed to formulate interpretations and understand the dominant discourses and hierarchies that construct notions of gender and sexuality within the patriarchal social system.

\section{RESULTS}

This research elucidates how gender and sexualities are discursive constructions that marginalise and oppress women within a patriarchal social structure. Butler's main argument of how "there is no 'natural body' that pre-exists its cultural inscription" (Salih, 2006, p. 55) reflects how gender and sexualities are constructed by society and are therefore, determined by cultural and social norms. This idea is addressed through Nora's gradual realisation of how she has been conditioned to perform the conventional role of a woman. She is marginalised and oppressed by patriarchal ideologies that exercise control over women's minds and bodies to sustain dominance over them. Her trajectory is reflective of the possibility for women to perform their gender and sexual identities differently. Hence, it further elucidates how these discursive constructions of gendered identities and sexualities are fluid and changeable. This drama reverberates the opportunity for women to break free from the socially inscribed values that ensnare them within conservative roles and ideals of womanhood.

\section{DISCUSSION}

Nora is a victim of institutionalised forms of marginalization that are designed to oppress women and contain them within their roles as daughters, wives and mothers. At the beginning of the play, Nora appears to fit into the ideals of a Victorian woman. She is a doting wife and a loving mother to her children. She is only expected to bear the responsibility of maintaining the household and to remain submissive to her husband. Words such as "my little lark" and "my little squirrel" (Ibsen, 1879, p. 6) that Torvald uses to address Nora show how she is infantilised and treated as someone who constantly needs his guidance in life because she is a woman. Furthermore, these pet names are reflective of Torvald's sense of superiority over Nora. He considers Nora to be nothing more than a possession or a 'doll' to be 'played' with, rather than an equal partner in marriage. The animal imagery used in the dialogues intensifies the dehumanizing treatment suffered by Nora within the household where she is seen "as less than human, a mere pet he owns" (Lavender, 2008, p. 122). Interestingly, Nora too responds to this demeaning treatment by playing the role of an ignorant, timid wife in order to feed Torvald's ego. The concept of performativity discussed by Judith Butler (2006) becomes applicable to the way in which Nora performs the role of a Victorian woman. As Butler argues, "gender is the repeated stylization of the body, a set of repeated acts within a highly rigid regulatory frame that congeal over time to produce the appearance of substance, of a natural sort of being" (Butler, 2006, p. 45). Nora has been conditioned into 'being' a woman through repetitive practices of her gender role that society has imposed on her. Her submissive behaviour is considered as the norm or as something that is 'natural' due to the fact it is in accordance with the regulations or beliefs of society. Hence, Nora's character is representative of culturally constructed identities and gender performances that mould one into a 'woman'. This idea can be linked to Simone de Beauvoir's argument that "one is not born, but rather becomes, [a] woman" (1947, p. 330). Thus, Nora too 'becomes' a woman by being subjected to social values, practices and norms perpetuated to maintain patriarchal dominance. She suppresses her 'true' character in order to identify with the socially constructed image of a woman. This highlights how gender is a discursive construction that oppresses women within an androcentric social structure. It is her behaviour, monologues or her relationships with Mrs. Linde, Doctor Rank and Krogstad that bring out the complexity of her character which is hidden behind the facade she maintains to please Torvald and society. As the play progresses, Nora finds the agency to construct her own identity that is free from societal pressures and expectations. As Salih mentions, the concept of agency was of central importance to Butler because "it signifies the opportunities for subverting the law against itself for radical, political ends" (Salih, 2006, p. 55). Nora redefines her status as a woman by 'subverting the law' of her contemporary society that discriminated and oppressed women based on discursively constructed gender biases. She starts forming her own individuality by saying "I must stand quite alone, if I am to 
understand myself and everything about me" (Ibsen, 1879 , p. 203). This is a moment that radicalized $19^{\text {th }}$ century theatre by depicting women as strong, independent characters. This can also be linked to the idea of situated freedom through which Simone de Beauvoir "seeks to theorize women's situation as constituting the struggle with the pervasive idea that motherhood constitutes women's personal and psychological fulfillment." (Marso, 2012, p. 1). Accordingly, Nora's struggle to find freedom is inhibited by this 'situation' where motherhood is equated with womanhood and individual desires are only allowed to exist within the confines of her socially prescribed gender role. However, triggered by her gradual disillusionment, Nora begins to question the inferior position she has been assigned within the household and the larger society for the first time in her life. It is an important step that helps Nora become an individual who has the freedom and ability to think and act on her own. Hence, she ventures beyond her socially constructed self to explore her own identity as a woman and as a human being.

The idea of gender performance is brought to an almost tangible level through the references to the Tarantella and the rehearsals prior to the party. This also marks a climatic moment in the plot where the idea of Nora emerging out of the conventional image of a woman is captured. The mythical references to the fatal bite of the Tarantula spider which was believed to cause an extreme restlessness that would eventually lead to death, becomes symbolic of the impending catastrophic change in Nora's life. The instance where she dances to the fast, upbeat tempo that is characteristic of the Tarantella dance is a significant moment through which Ibsen provides a glimpse into Nora's inner psyche. The lack of a set rhythm and the chaotic movements become metaphorical of how Nora is trying to go against the pattern of social behavior prescribed for her. Nora is a woman who is struggling to understand her position in society as a woman. She gradually realizes the oppressive nature of her marital relationship and how her personal desires have been smothered by social conventions. This conflict between the self and the society can be analysed based on Gilbert and Gubar's theory of the two antithetic identities that society has attributed to women. Within the limited world women can inhabit they are given two options; "if they do not behave like angels they must be monsters" (Gilbert and Gubar, 1979, p. 43). Nora has been conditioned to repress her creativity, dreams and aspirations to behave according to patriarchal social expectations. Her suffering is reflective of how women have been framed within conventional roles that destroy their agency and freedom. Moreover, Nora's actions are imbued with sexual connotations that elucidate how she is exploring her sexuality as a woman which has been cruelly stifled by patriarchal ideologies. As Cixous (1976) also highlights, the vibrant sexualities and desires of women have been suppressed due to feelings of guilt, fear and shame that are instilled by the male-dominated system to prevent women from "mak[ing] trouble" (p. 876). The way in which women have been robbed of their own bodies and sexualities is highlighted when Cixous states that patriarchy has ingrained a "stupid sexual modesty" (1976, p. 885) in women to prevent them from establishing an identity that is free from societal regulations. Nora too has been conditioned by these ideas of gender and sexuality. However, this moment becomes a significant instance that marks the unravelling of Nora's character. The way in which she temporarily strays from socially ascribed gender roles and expectations by continuing her frenzied dancing metaphorically shows how she stops being an 'angel', and thereby becomes a 'monster' in the eyes of society. Torvald is shocked by his wife's breach of social decorum as evident when he exclaims "stop... this is sheer madness. Stop, I tell you" (Ibsen, 1879, p. 147). Torvald's reaction is symbolic of how the patriarchal social structure aims to control or chastise women who venture beyond their social roles. Torvald makes a desperate attempt to control Nora, but she directly refuses to heed his advice for the first time in the drama. This is suggestive of how Nora is beginning to establish her authority within the household and the larger society by defying longstanding norms and conventions.

Moreover, the way in which Nora uses this dance to convey her emotions points to the absence of a discourse for women to articulate and express their own oppression. It is the only mode through which she can release her frustrations of having to live her life within a rigid framework of social norms. Nora's wild and frantic movements are reflective of her inner emotional turmoil which is hidden beneath the facade of a timid, mild-mannered Victorian wife. The fatality associated 
with the term Tarantella is also suggestive of a dance of death. Nora performs this dance as her final moment of uninhibited self-expression and creativity. Her anxieties over the revelation of her secret, her emotions and the vibrant energy that she was forced to repress are powerfully released through this moment. As Torvald says, Nora is "dancing as if her life depended on it" (Ibsen, 1879, p. 147). Ironically, it is Nora's performance that delays Torvald from discovering her secret. Hence, her future does depend on her actions that prevent Torvald from reading Krogstadt's letter that will bring about a massive change to their lives. Furthermore, it is also interesting to note how any emotional expression is brought out through some sort of performance within the play. Ibsen (1879) uses such dramatic and powerful bursts of energy or actions as a tool through which the psychological dimensions of his characters can be understood. For example, this Tarantella dance and the rehearsals are representative of the tormented interior of Nora's character. Her actions are quite contrary to the image of a submissive wife she attempts to uphold. Similarly, in the drama Hedda Gabler, Ibsen juxtaposes the image of the guns and the piano to bring out Hedda's conflict with the gender norms inscribed on her by society. The piano which is generally associated with femininity is used by Hedda as an expression of relentless power and violence. She releases her pent up energy and frustrations by playing the piano in a wild and chaotic manner. This can be linked to Butler's argument of how "gender is always a doing" (Butler, 2006, p. 34). The actions of dancing and playing the piano can be understood as part of their gender performance. However, these ruptures within their socially prescribed roles as exemplified through the actions of Nora and Hedda reflect how women can 'do' gender differently (Butler, 2006). Ibsen attempts to show how women are human beings above all else. It is only upon Nora's realisation of who she is as a human being that can then embody the other aspects of her gender identity she may choose to embrace. Therefore, this play is a powerful embodiment of the artificiality of gender identities and sexualities which relegate women into marginal positions while positioning men in the centre.

Furthermore, the concept of the home and Victorian domesticity is rooted in the representation of women as domestic beings. Women are seen as the epitome of the moral, social and material image of the home. Nora becomes the idealized version of the middle class Victorian woman by acting as the self-sacrificial, caring wife and mother while fulfilling household responsibilities and maintaining the material respectability of the home. She is "under a cultural compulsion to become one" (Butler, 2006, p. 11) to blend into the patriarchal structure that is governed by strict demarcations of gender. Women are acclimatized into their marginal positions by men so that they can continue their dominance over women. As Cixous (1976) argues,

Men have committed the greatest crime against women. Insidiously, violently, they have led them to hate women, to be their enemies, to mobilize their immense strength against themselves, to be the executants of their virile needs. They have made for women an antinarcissism! A narcissism which loves itself only to be loved for what women haven't got! (p. 878)

The voice and agency of women have been discarded for generations by brainwashing them into accepting their subordination. This 'antinarcissim' has prevented women from embracing their own lives, bodies and minds. Women have been alienated within their homes, their relationships with other women have been destroyed, their needs and desires have been smothered. The policing of their bodies as well as their minds are powerfully captured through the instance where Torvald is sexually aroused by Nora after the Tarantella performance and demands that she attend to his desires. Providing sexual gratification is seen as a part of her duty as a woman and a wife. Hence, it is clear that Nora's ownership of her own body is limited and her own sexual needs are not recognized. The way in which Torvald forbids her from eating macaroons or asks her to dress as a "Neapolitan fisher-girl" (Ibsen, 1879 , p.92) for the party are also examples of how he exercises power over Nora's body. Thus, Nora's plight as a woman within a repressive environment that functions upon rigid gender and sexual demarcations is made evident. Additionally, the concept of a home is governed by dichotomized readings of masculinity and femininity. This "masculine/feminine binary" (Butler, 2006, p. 6) can be seen as a dominant factor that 
influences societal perceptions of how men and women should function. Nora is constantly seen within the drawing room where ideals of Victorian womanhood are played out while Torvald occupies his office, a space that is symbolic of work, achievement and manhood. Thus, the private sphere of the home is represented by Nora and the public sphere is represented by Torvald. This spatial reading becomes important to understand the way in which Nora dismantles these boundaries by walking out of her marriage. The stage directions of the door being slammed shut at the end of the play is a powerful moment that symbolizes the fracturing of this dichotomy. Nora enters a sphere that is forbidden for her because she is a woman. Her journey is therefore, representative of the historical transition of the domesticated Victorian woman into the New Woman. At the onset of the play, Nora is aware yet uncritical of her domesticated position within the household. It is only after the secret of their debt to Krogstad is revealed that she understands how their marriage depends on her being under the complete authority of her husband. This is what allows Nora to understand the importance of agency and propels her desire to break free from the oppression. The instance where Torvald says that Nora is an unfit mother who can no longer be trusted with the upbringing of her children marks the shattering of the illusion of Torvald's love for her. She then realizes the extent to which she has been oppressed and discriminated throughout her life. This "pattern of domination" (hooks, 1984, p.26) is evident when Nora says, "our home has been nothing but a playroom, I have been your doll-wife, just as at home I was Papa's doll-child; and here the children have been my dolls" (Ibsen, 1879, p.201). This highlights how women were treated as objects within the Victorian society. The lifelessness, lack of control and fragility associated with the image of a doll is reflective of the way in which Nora is toyed with or exploited by those around her. The concept of the New Woman challenged these perceptions by giving the understanding that women strive for a sense of fulfillment and independence as opposed to adhering to conventional stereotypes. Thus, Nora rebels against her socially constructed gender identity in order to form one that is free from oppression.
Nora directly challenges the social structure that is governed by patriarchal ideologies and power hierarchies. This becomes a central mode through which her transition into the New Woman occurs. In commenting about the play, Ibsen himself wrote that "a woman cannot be herself in contemporary society. It is an exclusively male society with laws drafted by men and with counsel and judges who judge feminine conduct from a male point of view" (Joyce, 2016, p. 1). Social constructs such as religion and law that are supposed to exist for the betterment of people are detrimental to their existence. This is made evident through the fact that women were not allowed to borrow money without the consent of a man. Nora is driven to take extreme measures in order to save her husbands' life and once again falls prey to the manipulative control of a man; Mr. Krogstad. Nora is disillusioned when she realizes that "the law cares nothing about motives" (Ibsen, 1879, p.74). Her utter helplessness is made clear when her husband, Torvald says that what Nora has done by going against the legal and moral expectations of society makes her "a criminal" (Ibsen, 1879, p. 188). Nora is forced to acknowledge the fact that her position as a woman within their household and the larger society is controlled and shaped by deeply rooted patriarchal ideologies. Moreover, financial independence was a major aspect of the image of the emerging New Woman that is in direct contrast to the domesticated, dependent woman of the Victorian context. Nora is willing to lose her status, financial support and her family in order to form an identity for herself. The fact that she rejects any financial or material help offered by Torvald by stressing that there should be "perfect freedom on both sides" (Ibsen, 1879, p. 214) is reflective of the extent to which she desires to be liberated from the oppression she was subjected to throughout her life. It is this massive sacrifice and courage presented through the trajectory of Nora that makes the play so profound and radical. This becomes one of the reasons for A Doll's House (1879) to be considered as "one of the ground-breaking modern literary texts that established in fundamental ways the responsibility and cost of women's liberation and gender equality" (Mambrol, 2020, p. 1). Furthermore, Ibsen (1879) also discusses the idea of choice by highlighting how women are only presented with very few possibilities of transforming their oppressive 
conditions. Nora is restricted even within her opportunities to choose a different lifestyle. Nora decides to leave her marriage and family within a context where women are left helpless without the support of a man, either the husband or the father. She does so within a society that is preoccupied with social status and money. Her choice of leaving her home and her marriage is fused with the threat of social chastisement, unemployment and alienation. This highlights the tragedy of womanhood with a patriarchal society governed by rigid constructions of gender identities and sexualities. The normative behaviour expected from women based on patriarchal constructions of gender and sexualities frames women like Nora within an oppressive structure that destroys freedom and individuality.

Nora's disillusionment of her position as a woman in the $19^{\text {th }}$ century Norwegian society becomes a powerful platform through which Ibsen voices the detrimental effects of following strict social codes and practices. The events that unfold with the gradual realisation of her dependency and helplessness pave the way for Nora to take control of her own life. Gender and sexuality become concepts that are constructed in a way that marginalises women and locates them in the periphery, while their male-counterpart always remains at the center. However, the way in which Nora regains authority over herself is reflective of the idea that the marginal position she occupies in her society has been transformed by her into "a site of radical possibility, a space of resistance" (hooks, 1990, p. 341) through which she can challenge dominant patriarchal ideologies. Nora deciding to leave her husband, her children and her home was not only a shocking moment in European theatre, but also an important point that pushed society towards understanding the need to break free from tradition. The notion that a woman was able to reject the identity imposed by society and embark on a journey to find herself was almost unthinkable in a society that vehemently depended upon convention. Nora steps beyond her role as a wife and a mother by realizing that she has "other duties just as sacred" (Ibsen, 1879, p. 205). This liberal standpoint that emphasizes individual freedom is a key characteristic of the emerging New Woman. It directly opposes the hegemonic constructions of gender norms and sexual identities that have been imposed upon women by patriarchy. Ibsen (1879) seems to uphold and perpetuate feminist ideologies through his plays as seen through how Nora finds the courage to construct her own identity by defying what society expects from her as a woman. Although this may have not been the original intention of writing the play, Ibsen addresses the issue of individual freedom and the existential crisis experienced by people during the late $19^{\text {th }}$ century which resonated with the emerging concepts of female independence and gender equality. Therefore, while $A$ Doll's House (1879) becomes a radial play that brings forth feminist ideologies, Ibsen also focuses on issues beyond the position of women in society. As Lavender (2008) argues,

\section{If Ibsen gives us in A Doll's House his first fully realized heroine, he also proclaims through the exploration of her psychology what he feels to be intrinsic and necessary to the life of the true human being: freedom (p. 9).}

The identity of human beings, the complexity of their relationships, their trajectories are aspects that are highlighted in his plays and the need for "freedom" lies at the core of Ibsen's work. Therefore, the transformation of Nora from being a woman without a sense of individuality into an independent person who yearns to be true to herself can be understood through these elements discussed by Ibsen (1879). Thus, the liberation of the self from social barriers was seen as a central mode through which a woman could break free from the generational oppression that aimed to control and suppress women. Reclaiming agency over mind and body becomes essential for Nora to emancipate herself from social restraints. can perform her gender and sexuality differently while challenging the artificially constructed identities imposed by the patriarchal social structure that aims to discriminate women.

\section{CONCLUSION}

In conclusion, $A$ Doll's House (1879) by Ibsen is a play that radicalizes the position of women in society by focusing on the transformation of Nora from a timid, domesticated woman into a woman who yearns to be independent and true to herself. Nora's courageous act of leaving her home, her husband and children to find 
herself becomes a symbol of the possibility for women to achieve liberation from oppressive power structures and social constructs. Her actions are in direct defiance of the patriarchal values and norms that were practiced during this period. The conventional interpretations of gender and sexuality have been dismantled through the revolutionary actions of Nora in shedding her socially prescribed identity. Hence, this is a play that marks the emergence of the New Woman where the oppressive Victorian ideals of womanhood are challenged and eliminated. The character of Nora is representative of the struggle for female independence and empowerment that paved the way for the historical transition of women from being generic family members into becoming individuals. Thus, the subordinate position women were compelled to inhabit within a patriarchal social structure is questioned by interrogating the artificiality of gender and sexualities.

\section{REFERENCES}

Butler, J., (1990). Gender Trouble. Reprint 2006. New York: Routledge Classics.

de Beauvoir, S., (1949). The Second Sex. [e-book] New York: Vintage Books. Ch. 1. Available through: Uberty <https://uberty.org/wpcontent/uploads/2015/09/1949_simone-de-beauvoirthe-second-sex.pdf> [Accessed 28 June 2021].

crossref-it.info., (2021). Naturalism and realism, [online] Available at: <https://crossrefit.info/articles/518/naturalism-and-realism > [Accessed 18th April 2021].

Cixous, H., (1976). The Laugh of the Medusa. [online] Available at: 〈http://www2.csudh.edu/ccauthen/576F10/cixous.pdf> [Accessed 14 September 2021].

Gilbert, S. M. and Gubar, S., (1979). The Madwoman In The Attic" The Woman Writer and the NineteenthCentury Literary imagination. [e-book] London: Yale University Press. Ch. 1. Available at: <http://www.ricorso.net/tx/Courses/LEM2014/Critics/ Gilbert_Gubar/Madwoman_full.pdf $>$ [Accessed 31st July 2021].

hooks, b., (1984). Feminism: A Movement to End Sexist Oppression, [online] Available at: <https://duca94.files.wordpress.com/2011/05/hooks00 1.pdf $>$ [Accessed 29 June 2021]

hooks, b., (1990). Marginality as a Site of Resistance. pp. $341-343 . \quad$ Retrieved from http://pzacad.pitzer.edu/ mma/teaching/MS80/reading s/hooks.pdf [Accessed 2 September 2021].

Ibsen, H., (1879). A Doll's House, [online] Available at: $<$ https://www2.hf.uio.no/polyglotta/public/media/libra ries/file/10/A\%20Dolls\%20House$\% 20 H e n r i k \% 20 I b s e n . p d f>$ [Accessed 29 June 2021].

Joyce, S., (2016). Little Eyolf: An Unconscious Feminist, [online] Available at: $<$ https://almeida.co.uk/little-eyolf-an-unconsciousfeminist $>$ [Accessed 18 April 2021].

Lavender, J., (2008). Seeking the Greatest Miracle: Psychological Mythology in Ibsen's A Doll House. [online] Available at: $<$ https://kb.gcsu.edu/cgi/viewcontent.cgi?article $=10$ 56\&context=thecorinthian $>$ [Accessed 21 April 2021]. Mambrol, N.,(2020). Analysis Of Henrik Ibsen's A Doll's House. [online] Available at: $<$ https://literariness.org/2020/07/27/analysis-of-henrikibsens-a-dolls-house/> [Accessed 21 April 2021].

Marso, L. J., (2012). Thinking Politically with Simone de Beauvoir in The Second Sex. [online] Available at: $\langle$ https://muse.jhu.edu/article/478359> [Accessed 15 October 2021].

Salih, S., (2006). On Judith Butler and Performativity. [online] Available at: <http://www2.kobeu.ac.jp/ alexroni/IPD2020/IPD2020\%20No.2/SalihButler-Performativity-Chapter_3.pdf> [Accessed 3 July 2021]

Walby, S. (1990). Theorizing Patriarchy. [e-book] Oxford: Basil Blackwell Ltd. Ch. 1 Available at: <https://openaccess.city.ac.uk/id/eprint/21680/1/1990_ Walby_Theorising_Patriarchy_book_Blackwell.pdf> [Accessed 15 October 2021]. 